China Perspectives

45 | january-february 2003

Varia

\title{
Peking Between Modernisation and Preservation
}

\section{Aurore Merle et Peng Youjun}

\section{OpenEdition}

Journals

Édition électronique

URL : http://journals.openedition.org/chinaperspectives/233

DOI : 10.4000/chinaperspectives.233

ISSN : 1996-4617

\section{Éditeur}

Centre d'étude français sur la Chine contemporaine

\section{Édition imprimée}

Date de publication : 1 février 2003

ISSN : 2070-3449

\section{Référence électronique}

Aurore Merle et Peng Youjun, " Peking Between Modernisation and Preservation », China Perspectives [En ligne], 45 | january-february 2003, mis en ligne le 23 novembre 2006, consulté le 28 octobre 2019 URL : http://journals.openedition.org/chinaperspectives/233; DOI : 10.4000/chinaperspectives.233

Ce document a été généré automatiquement le 28 octobre 2019

(c) All rights reserved 


\title{
Peking Between Modernisation and Preservation
}

\author{
Aurore Merle et Peng Youjun
}

\section{NOTE DE L'ÉDITEUR}

Translated from the French original by Nick Oates

1 Organised on the initiative of the Tsinghua University School of Architecture, the Tibet Heritage Fund, the Ecole française d'Extrême-Orient (French School of the Far East) and the Observatoire de l'architecture de la Chine contemporaine (Observatory of Research in Architecture in Contemporary China), the colloquium on the future of old Peking sought to bring together Chinese and foreign specialists to share their experiences and, more urgently, arrived at some conclusions and proposals on the way forward for the Chinese capital city. The first day was given over to consideration of the official policies on the conservation of the national heritage in China, with contributions from architects and town planners, but also in Europe, in particular in Germany and France. Going beyond a simple inventory of the current legal and regulatory framework, the undertaking served to highlight the major problems presently confronting the management of China's national heritage: how to reconcile the development of tourism with the protection of that national heritage? Does conservation have to be devoted to monuments or should the aim be to preserve the environment in which those monuments are recorded? The second day was dedicated to exchanging experiences in conservation and to reviewing study and restoration projects involving old districts in cities such as Xi'an and Lhasa but above all in Peking. At the end of the colloquium, which provided a rich seam of debate, what can be said about China's present-day policy on the conservation of its national heritage? What obstacles lie in the way of the implementation of this policy and the management of that heritage? And what solutions were put forward by the participants in the colloquium? 
The policy of the conservation of the national heritage in China

2 Despite the destruction that is in progress, Peking is the only capital of the Chinese empires that is still visible. What is at stake in the protection of Peking is thus crucial for the general protection of China's national heritage, as it constitutes an example for other Chinese cities. According to Professor Zhao Zhongshu, Peking has existed as a city for more than three thousand years and as a capital for more than eight hundred years. It was built according to traditional and austere architectural rules, and despite the dynastic changes, the evolution of the city has been slow and very structured. Peking was conceived as a harmonious whole. Today, 25 "protected zones" have been classified (or rather conceded) within the city. This already represents some progress, but it is far from sufficient. What is even more inadmissible is that each individual district draws up its own urban planning projects.

Since 1949, the Chinese government has progressively instituted legal measures in the field of the protection of the national heritage at the municipal level, the neighbourhood level and at the level of individual buildings. Nationally, three distinct administrations are responsible for the protection of the national heritage: the State Administration of Cultural Heritage, the Ministry of Construction for the protection of historic cities and the Ministry of Culture for the protection of the heritage that is referred to as non-material. Finally, there are two kinds of lists for the protection and conservation of the cultural heritage: that of the "officially protected heritage sites" (wenwu baohu danwei), and that of "historically and culturally famous cities" (lishi wenhua mingcheng). At the end of 2001, 1,268 officially protected heritage sites were recorded at the national level and 7,000 at the provincial level. 101 cities are classified as "heritage cities" at the national level.

Since 1949, several sets of provisional regulations have contributed to the protection of the national heritage. On May 24th 1950, the government published two such regulations, one prohibiting the export of objects and books classified as national treasures, the other regulating excavations of sites and tombs. This was the first time since the establishment of the People's Republic that the concept of "cultural heritage" had been evoked. Through these regulations, the protection of the cultural heritage now came under the competence of the government, which has the right and the duty to conserve it. It was also the first time that a distinction was made between the different values inherent in the national heritage: cultural, revolutionary, historical, etc.

5 In the light of the destruction of so many historical buildings, the government issued a directive on July 6th 1950 emphasising the conservation of the ancient aspect of the national heritage. On May 7th 1951, the government and the Ministry of Culture conjointly published three regulations: the first concerned the assignment of the rights and duties within the management of heritage sites; the second related to the means used to protect regional heritage sites; and the third set out the organisation of the committees appointed to manage the heritage at the regional level. These regulations imposed a structured system for the protection of the heritage by specifying the competencies of the different organisations. Above all, they contributed to the institutionalisation of heritage protection: management committees were established in provinces that enjoyed a wealth of heritage treasures.

On October 12th 1953, the government published a directive to protect the "historical and revolutionary heritage" of buildings. And on April 2nd 1956, in a circular on the 
protection of the heritage in agricultural activities, the government drew up a list of "officially protected heritage sites". It was in the 1960s that the first national heritage survey (by surface area) was conducted. And on March 4th 1961, the State Council published the first list of "important entities for the protection of the national heritage". The provinces and the cities subsequently drew up their own lists.

In 1982, the government classified 24 cities in the initial list of "historically and culturally important cities" (lishi wenhua mingcheng). In 1986, a second, then a third list appeared (adding 38 and 37 cities respectively). Two other cities were added in 2001. A total of 101 "historically and culturally important cities" can be counted today.

Thus, contrary to received ideas, there are sufficient laws and regulations in China for the protection of historical cities. The problem resides in the failure to apply them. How can observance of the laws be realised in a country such as China, which is still not a state based on the rule of law?

A policy of conservation in conflict with other policies of urban development

Although it has been possible for the conservation of the national heritage to materialise within a set of laws and regulations, it has come into conflict with other policies, such as those to improve transport or to develop green spaces. As underlined by Song Xiaolong, architect at the Peking Municipal Institute of City Planning and Design, the only participant representing an official institution, transport plans are currently decided on the sole criterion of efficiency and do not incorporate any consideration of the city's traditional structures. The widening of roads carried out to improve traffic circulation not only destroys the old urban fabric, but also has repercussions at the economic level as a result of the disappearance of small local businesses and the hustle and bustle of the neighbourhood districts.

The policy that most threatens the conservation of the old city is the one that concerns the "reform of dangerous residential buildings" (weifang gaizao). Here, the boasted objectives of modernisation and the improvement of housing conditions leave the way open for the destruction of entire neighbourhoods, accompanied by the relocation of the original inhabitants, in order to construct new homes at higher prices and in architectural styles that show little respect for the harmony of the city. For writer Shu Yi, when this policy was first implemented on Peking's peripheries, it was not a very serious matter as monuments and houses of historical value in these areas were rare. Now, however, this development has extended to touch the very heart of Peking; it is a genuine danger for the imperial city (huangcheng) and has clearly to be opposed: "The power to reform the old districts should not be placed in the hands of the developers".

11 An example that is still sharp in the minds of the defenders of the national heritage is the house situated at no. 22 of the road Meishuguan houjie, where a siheyuan ${ }^{1}$ of great value was destroyed as part of the works to widen Ping'an Avenue. In this connection, Shu Yi denounced the power of money and the collusion between political decisionmakers and property developers: "Everything is a question of money. Behind the real estate, there is money. The relations between these characters are thus: you have money there; the property developers are here, and the government is there: they form a circle and behind it there is always money".

12 Song Xiaolong, through the post that he occupies, does not express the same virulence as Shu Yi. He does recognise, however, that the policy of weifang gaizao is in conflict with the projects of his institute, in particular the implementation of the principle of renovation by stages and over mini-zones (weixun huanlun). He also painted a picture of 
the pressures that exist when the official lists of monuments and districts to be protected are drawn up. While the interests of these different actors-heritage offices, property developers, etc.-seem to stand in opposition to each other, they are sometimes very tightly interwoven, and those who officially protect the heritage are sometimes the first to destroy it. Thus, in a list of property developers published by the Ministry of Construction, the company Dongfang kangtai appears as an entity that belongs to the heritage office of the district of Dongcheng. The plurality of the functions of administrator and entrepreneur renders the possibility of any checks and balances or any recourse to the law particularly difficult.

The heart of the problem lies in the application of the law. When journalist Liu Xudun mobilised a protest at the end of the 1990s in Zhoushan in Zhejiang province to stop the destruction of the old town (or rather, what was left of it), he initiated a lawsuit to prevent his family home from being destroyed. He then discovered that the local government was putting pressure on the local courts and on the media: "Those who are carrying out the destruction are not the laobaixing (the people), but the governments and the officials". Another evocative example is that given by Liang Congjie, historian and president of the Association of the Friends of Nature, during the round table which brought the colloquium to a close. Having written a letter to the secretary general of the State Council to point out to him that the tower in Dongfang square exceeded the legally permissible height, it was explained to him over the telephone by the secretary general that he knew this was against the law, but that he himself did not have the power to prevent it. "If he doesn't, who does?" Liang concluded.

Recourse to justice is made difficult by the legal status of property, a problem brought up extensively during the various contributions. Writer Hua Xinmin (Catherine Xia) recalled the legal evolution of the status of land since 1949. After 1949, even though the state carried out expropriations and implemented a policy of nationalisation, at the legal level the land did not belong to the state. Landowners were given a certificate of ownership and each month they paid land taxes. With the outbreak of the Cultural Revolution, numerous landowners "lost" their certificates and found themselves compelled to accept new inhabitants. From 1976, the landowners were able to recover their certificates, on the condition that they did not chase off the inhabitants who had arrived during the Cultural Revolution. Contrary to what is often thought, it was thus not until 1982 that the land, in the cities, became the property of the state. But if the urban land now belongs to the state, the owners retain a right of use of the land of indefinite duration. According to the law, it is not possible to sell the land on the market, but only the right of use pertaining to it. By virtue of this complexity, numerous owners are not aware of their rights and the property developers illegally deprive them of their rights.

The conflict between conservation of the national heritage and the development of tourism

This question was extensively discussed during the colloquium, notably in the form of a debate chaired by Françoise Ged with Jean Rouger, vice-president of the National Association of Cities and Countries of Art and History. Addressing himself to Jean Rouger, one questioner emphasised the specific Chinese characteristics of the contradiction between conservation and tourism: "For the officials, the problem is: how can we earn money? They only see tourist resources in the monuments and not cultural resources. This is a phenomenon that spreads down from the top to the bottom. The 
civil servants say to themselves, if I can earn some money, I will invest all my efforts into protecting and managing our heritage. If I can't, I am not going to protect or manage it". The questioner illustrated his theme through the province of Shandong, and through two cities that have chosen contrasting models for the conservation and exploitation of their heritage. Qufu, in the area of Confucius' birthplace, has opted for an intensive exploitation of its heritage to the profit of tourism, a choice that has led it to construct false monuments. The elevated earnings from tourism of this city contrast sharply with the difficulties faced by a neighbouring village, which has elected to give priority to protection, to respecting the rule of conservation, but which barely manages to attract any tourists: "It is thus the market that sets the value and it is according to this value that the methods of protection are decided on. This represents a very grave danger, because the market is blind". In response to this example, Jean Rouger lays stress on the fact that in France there is a clear dissociation between protection of the national heritage, guaranteed by representatives of the state, and its exploitation. China is far from committed to a separation of functions since, as mentioned by one participant, around two years ago the work of conservation was entrusted to the care of the tourism offices. The only limit on these diversions, according to Lü Zhou, architect and professor at the Tsinghua University School of Architecture, is the recent publication of a regulation confirming that the heritage conservation units cannot become private enterprises.

The subordination of the cultural heritage to economic interests leads as a consequence to the favouring of rapid renovations catering to the tastes of tourists to the detriment of genuine restoration work. According to Lü, "in China, the renovation work is sometimes of a very bad quality, and we would be better off not renovating anything, there is a lack of people who possess the technical ability to restore historical monuments". The problem of the quality of the conservation can be related to the absence of state certification of the competence of the restorers. Indeed, as architect and town planner Alain Marinos underlined, there exist in France bodies of professionals in the building trade which, under the supervision of the state, award qualifications, a certain number of which concern the restoration of historical monuments. To obtain contracts, companies have therefore to provide proof of their specialist skills. Moreover, financing is only granted subject to it being used by approved professionals. The work on the cultural heritage consequently demands that all levels of the restoration process are professionalised to a much greater extent.

The focus on tourism and economic exploitation of the cultural heritage raises the problem of the functions and value of this heritage. Can it be reduced to its economic and tourist value? Liang Congjie called to mind the problem of the lack of sensitivity of the political decision-makers, of the population and of a number of experts to the historical value of the heritage. If Wu Liangyong, an expert in the history of the urban development of Peking, declared "that it was never too late to start", the question is knowing whether the decision-makers in the government, the residents and the experts have any awareness of the fact that the protection of old Peking is today indispensable. In reply to Wu Liangyong, Liang Conjie stated: "if people refuse to get down to the task, it will always be too late".

Conservation centred on the monument or on the environment: the problem of the population 
(1) prevent the complete disappearance of old Peking. At the moment, only thirty zones are officially protected within the city's boundaries. A proposal is needed to increase this list in one go by 300 other zones that have already been surveyed by experts (on a waiting list). Even if it cannot totally prevent the destruction, official registration on the list can nevertheless constitute a weapon for the defenders of cultural heritage. Similarly, of the 3,000 siheyuan surveyed in Peking, around six hundred have an important value as heritage sites and must be conserved. The Heritage Office has this list in its possession but has not published it yet. The official publication of this list is a high-stakes chip both for the 
defenders of the cultural heritage and for the property developers. For if these siheyuan are officially recognised as requiring protection, they will become "star turns" nailed into the urban landscape of Peking, something that will make it difficult for zones to be totally destroyed and for architects to design their urban projects.

But protection by the law is only possible through social mobilisation: "it is necessary that the experts and the general population unite with each other in a partnership to defend their heritage", says writer Yuan Li, who suggests creating an association for the protection of the cultural heritage following the conference. Liu Xudun has demonstrated that at Zhoushan it was through the mobilisation of the residents and their legal fight that protection was possible. These forms of collective legal action are also being conducted in Peking, but come up against more obstacles. The sensitivity of Chinese and international opinion and the mobilisation of the media make up an integral part of the fight for protection. It is in fact by providing information on the laws, the rights of the owners and the illegal activity pursued by the property developers that pressure can be exerted on the political decision-makers.

Combining protection of the heritage and modernisation of living conditions

In addition to action to prevent the destruction of the cultural heritage, projects to renovate old districts being conducted in other cities in China were also presented. The one headed by Bruno Fayolle-Lussac in a district of Xi'an may represent one possible path for renewal and restoration. The decision had been taken to refuse to change the public spaces but to retain the initial structures, in particular the width of the roads. By compromising the system of small plots of land as little as possible, it proved possible to let the residents reconstruct their space themselves. The results of this project have turned out to be overwhelmingly positive: the district has been successfully transformed, with the emergence of a road where businesses specialising in calligraphy proliferate, all the while conserving the life of the neighbourhood.

Zou Huan, architect at Tsinghua University, and Hirako Yutaka, of the Tibet Heritage Fund, presented a survey and pilot renovation project for three residential zones in old Peking. The aim of their research into the living conditions of the inhabitants was to provide material that would enable a residential zone to be improved and the structure of the social life to be conserved. At the end of their investigation, Zou Huan and Hirako Yutaka envisage finding financial solutions to encourage the residents who have other housing possibilities and who wish to move out to leave the dazayuan, so that a programme for the renewal of the housing stock can be started with the remaining residents. But, as Shu Yi underlines, to renovate the houses of the hutong, it is first necessary for the state to improve the public infrastructure, such as the sewage system, the electricity supply and the heating network. If the exterior is not modernised, it is impossible to even think of improving the living conditions on the inside.

Between excitement and disappointment

A very genuine excitement was generated during the discussions, for the participants all feel concerned and are conscious of the urgency of the situation. Disappointment, however, was visible on the faces of the contributors, who expressed their feelings of impotence. In conclusion, however, it is possible to highlight two positives. Although the colloquium certainly provided an opportunity to make comparisons with other Chinese and foreign cities, it was for the first time almost entirely dedicated to the protection of Peking. Above all, it facilitated the encounter between experts and militants from different environments. If the relative absence of representatives from 
officialdom and contacts with the media is to be regretted, it was important that the architects and the professionals who are conducting the restoration projects were able to meet those who day by day fight to halt the destruction.

\section{NOTES}

1. Siheyuan: a traditional house arranged around a square courtyard.

2. Dazayuan: a large traditional residence parcelled out into several individual homes. 